\title{
NEUROLOGICAL IMPROVEMENT IN TRAUMATIC INJURIES OF CERVICAL SPINAL CORD
}

\author{
By JERzY KIWERSKI and MARIAN WeISS \\ Rehabilitation Institute, Konstancin, Poland
}

Abstract. In 1965-78 930 patients with trauma of the cervical spine were treated in the Rehabilitation Institute of Konstancin.

Eight hundred and forty-three patients had spinal fracture and spinal cord injury. In this paper the effects on the neurological disabilities achieved in 468 patients with complete or severe spinal cord injury are discussed. Improvement after admission to hospital, and taking into account the patient's age and also the timing and the method of specialist treatment, is analysed.

Key words: Traumatic cervical spinal cord injury; Neurological improvement after treatment of cervical spinal injury.

\section{Introduction}

CERviCAL spinal trauma, complicated by injury to the spinal cord, constitutes the greatest problem of spinal departments, because of significant early mortality in this group of patients (Munro, I96I; Bombart \& Senegas, I97I; Bellamy et al., I973; Hackler, I977; Kiwerski \& Chrostowska, I977; Mesard et al., I978), as well as long-lasting treatment and later great dependence of patients on the environment.

In our considerations we restrict ourselves to discussing the group of patients in which, at the moment of starting treatment, complete motor paralysis from the level of injury has been ascertained.

However, in this series, two groups of patients should be distinguished:

(I) patients with symptoms of complete spinal cord injury-that is, with paralysis and absence of all kinds of sensation;

(2) patients with motor paralysis but with at least a trace of deep sensation preserved in the feet.

In the first group persistence of complete symptoms for over 48 hours had a bad prognosis. Tetraplegia was irreversible (Bosch et al., 197I), and improvement even with early and apparently correct treatment was infrequent.

The second group had a better prognosis, the neurological deficits quite often disappeared, sometimes at an early stage. In this group of patients early restoration of normal conditions within the vertebral canal is very important, independent of the type of treatment used, whether it is conservative or surgical.

\section{Clinical material}

From the moment of opening the Rehabilitation Institute at Konstancin in I949, over 3500 patients with spinal injury have been treated. However, comprehensive treatment in the early post-traumatic period was only started when a spinal cord department was established, and this became active from I965. From 
that time we treated about 2000 patients with spinal trauma in the early posttraumatic period (over 90 per cent of patients have been admitted within 48 hours after trauma). During $1964-78,930$ patients with cervical spine injury were treated and in 843 patients the trauma was complicated by spinal cord injury. In this paper we analyse a group of 468 patients with complete, or severe spinal cord injury, that is, patients in whom, on admission to the hospital, we found that there was motor paralysis at the level of spinal cord damage. Table I presents the age and the degree of spinal cord injury of the analysed group of patients. cent).

The majority of the patients were in the age group of 20-60 years (65 per

The group under discussion includes a greater number of patients with a complete (7I per cent) than with incomplete spinal cord injury.

In assessment of partial damage to the spinal cord we used a classification, from I965 (Hafter et al., I968), similar to that given by Frankel et al. (1969), and in which we defined three degrees of partial injury:

I. Spinal cord paralysis with even a trace of preservation of motor, deep sensation in feet (corresponding to group B of Frankel).

2. Pareses of considerable degree without functional importance (group $\mathrm{C}$ according to Frankel).

3. Insignificant pareses, allowing functional use of extremities (group D according to Frankel).

The group of incomplete injuries, presented in Table I, includes patients with first degree of partial damage, which corresponds to group B of Frankel's classification. Table II demonstrates the causes of spinal trauma in relation to the age of the patient most commonly found in our material.

TABLE I

\begin{tabular}{|c|c|c|c|c|c|}
\hline \multirow{2}{*}{$\begin{array}{l}\text { Neurological } \\
\text { status on } \\
\text { admission } \\
\text { (motor) }\end{array}$} & \multicolumn{4}{|c|}{ Patient's age } & \multirow[b]{2}{*}{ Total } \\
\hline & $\mathrm{Up}$ to 20 & $2 I-40$ & $4 I-60$ & Over 60 & \\
\hline $\begin{array}{l}\text { Complete } \\
\text { Incomplete }\end{array}$ & $\begin{array}{l}57 \\
19\end{array}$ & $\begin{array}{r}116 \\
52\end{array}$ & $\begin{array}{r}100 \\
36\end{array}$ & $\begin{array}{l}60 \\
28\end{array}$ & $\begin{array}{l}333 \\
135\end{array}$ \\
\hline Total & 76 & I68 & 136 & 88 & 468 \\
\hline
\end{tabular}

TABLE II

\begin{tabular}{|c|c|c|c|c|c|}
\hline \multirow{2}{*}{$\begin{array}{l}\text { Trauma } \\
\text { cause }\end{array}$} & \multicolumn{4}{|c|}{ Patient's age } & \multirow[b]{2}{*}{ Total } \\
\hline & Up to 20 & $2 I-40$ & $4 I-60$ & Over 60 & \\
\hline Fall from a cart & I & 17 & 57 & 53 & 128 \\
\hline Diving into water & 61 & 56 & 4 & 2 & I2I \\
\hline Fall from a height & 6 & 48 & $36^{7}$ & $2 \mathrm{I}$ & III \\
\hline Road accident & 6 & 42 & 27 & 8 & 83 \\
\hline Pressing down & 2 & 3 & 7 & 4 & I6 \\
\hline Others & - & 2 & 5 & $\begin{array}{l}4 \\
2\end{array}$ & 9 \\
\hline
\end{tabular}


As seen from the table there are in Poland four principal causes of acute spinal fracture in the cervical region; falling from a horse-cart (over 27 per cent) constitutes the main cause of cervical spinal trauma in the country; diving into shallow water onto the head (about 26 per cent); falling from a great height (trees, scaffolding, repairing a roof, etc. about 24 per cent); and road accidents, motorcars being the most frequent (about 18 per cent). Thus, these causes are quite different from those seen in America or in West European countries. (Selecki \& Williams, I970; Wilcox et al., 1970; Horlyck \& Rahbek, I974; Heiden, 1975; Meyer et al., I975; Carter, 1977.) Among the younger patients (up to 20 years of life), the principal cause of trauma is diving into water (over 80 per cent); in the next age group this cause is also common (over 33 per cent). Falls from a height and road accidents are also quite frequent.

Fall from a horse-cart is very common (about 42 per cent).

\section{Procedure tactics}

Our procedures are aimed at obtaining the following effects:

(a) Restoration of the normal condition within the vertebral canal,

(b) Stabilisation of the damaged spine,

(c) Prevention of complications, i.e. respiratory, neurological and decubiti in particular,

(d) Early tilting and adaptation to a position appropriate to the neurological status.

Restoration of normal conditions within the vertebral canal is obtained, usually by means of skull traction. If there are symptoms of complete or severe spinal cord injury we carry out manipulation under an anaesthetic with the addition of relaxation with drugs. On the other hand, if there is a minor spinal cord injury, correction of the spinal deformation with traction is proceeded with more slowly.

With dislocations in the lower part of the spine (C6-C7 and $\mathrm{C}_{7}-\mathrm{DI}_{1}$, especially in those with short necks and patients who are heavily built, there may arise the necessity for surgical reposition by an anterior operation (Bush \& Schürmann, I97I; Verbeist, I973; Kiwerski, 1979). The form of spinal stabilisation depends on the nature of the trauma. In compression, flexion or extension fractures, we treat the patients with skull traction for a period of 6-8 weeks and then apply an orthopaedic collar. If there is obvious instability continuing beyond this period the spine is fused by an anterior approach (Selecki \& Williams, 1970; Cloward, I97I; Verbiest, I973; Kiwerski et al., 1977).

We apply early surgical stabilisation in patients with explosion fractures where there is compression of the spinal cord by bony fragments and also in dislocations from flexion mechanism where there is no fracture, but in which we often find instability in spite of prolonged immobilisation (Kiwerski \& Makowski, I972; Makowski et al., I972).

The prevention of complications does not influence our use of general principles. Early adaptation of patients to the vertical position is possible, thanks to modification of our orthopaedic beds, which allows the patient to be tilted at a predetermined angle followed by inclining the bed, even if the patient has skull traction in place. This overcomes insufficiency of the vascular-respiratory system, which may later develop in patients changing from the wheelchair to the vertical position. 


\section{Neurological improvement}

The amount of neurological improvement is set out in successive tables in this paper, taking into consideration its dependence on the time of starting treatment in a specialised centre, and in relation to the patient's age and to the treatment used.

As is seen from Table III, the majority of patients reached our hospital within 24 hours from the injury ( 82 per cent). Significant neurological improvement was obtained in 156 patients (over 45 per cent). This improvement, however, in persons with complete spinal cord injury is relatively infrequent, being found in only 39 persons (constituting about 18 per cent of this group of patients). In our series improvement appeared in persons admitted for treatment during

TABLE III

\begin{tabular}{|c|c|c|c|c|c|c|c|}
\hline \multirow{2}{*}{$\begin{array}{l}\text { Neurological } \\
\text { status before } \\
\text { and after } \\
\text { treatment }\end{array}$} & \multicolumn{6}{|c|}{ Time of starting treatment } & \multirow[b]{2}{*}{ Total } \\
\hline & $\begin{array}{l}\mathrm{Up} \text { to } \\
6 \mathrm{hrs}\end{array}$ & $7-12$ & I3-24 & $\begin{array}{l}2-3 \\
\text { days }\end{array}$ & $\begin{array}{l}4-7 \\
\text { days }\end{array}$ & $\begin{array}{l}\text { Over } \\
\text { a week }\end{array}$ & \\
\hline$C-3$ & 3 & I & 2 & - & - & - & 6 \\
\hline $\mathrm{C}-2$ & 5 & 5 & 7 & - & - & - & I7 \\
\hline C-I & 4 & 5 & 6 & I & - & - & I6 \\
\hline $\mathrm{I}-\mathrm{n}$ & 4 & 2 & 3 & - & - & - & 9 \\
\hline$I-3$ & 19 & I4 & 25 & 6 & 2 & - & 66 \\
\hline $\mathrm{I}-2$ & 12 & 9 & 10 & 7 & 3 & I & 42 \\
\hline $\mathrm{C}-\mathrm{C}$ & 69 & 28 & 38 & I8 & 15 & I I & I79 \\
\hline$I-I$ & I & 3 & I & I & I & 4 & II \\
\hline Deaths & 38 & 42 & 29 & 9 & 3 & I & 122 \\
\hline Total & 155 & 109 & I2I & 42 & 24 & I7 & 468 \\
\hline
\end{tabular}

the first 24 hours following trauma. In patients admitted on the first day of their injury improvement was noted in 50 per cent of the cases, and in those admitted during the first week, in 35 per cent; on the other hand, in those admitted later, improvement only occurred in one patient. Death occurred in 122 patients, which constitutes 26 per cent of the group under discussion.

Table IV presents the neurological improvement in relation to the age of the patients.

We do not find a significant relationship between a patient's age and the number of patients who improved.

We observe that after 60 years of age improvement is less often seen than in younger patients. Also, in older patients the mortality rate is higher, increasing two-fold on average in each successive period of 20 years.

Table $\mathrm{V}$ demonstrates neurological improvement occurring after various forms of treatment.

The largest group constitutes those who were treated conservatively (over 6I per cent).

In this group the number of patients with neurological improvement is smallest ( 36 per cent), and the mortality is the highest (about 35 per cent). This is due in great measure to the fact that this group includes the greatest number 
TABLE IV

\begin{tabular}{ccccc}
\hline $\begin{array}{c}\text { Change in } \\
\text { neurological } \\
\text { status }\end{array}$ & Up to 20 & 2I-40 & 4 I-60 & Over 60 \\
\cline { 2 - 5 } & I & 4 & I & - \\
C-3 & 4 & 2 & 8 & 3 \\
C-2 & 3 & 7 & 5 & I \\
C-I & 2 & 5 & 2 & - \\
I-n & I3 & 22 & 2 I & 10 \\
I-3 & 5 & I5 & I2 & I0 \\
I-2 & 42 & 82 & 46 & 9 \\
C-C & - & 8 & 2 & I \\
I-I & 6 & 23 & 39 & 54 \\
Deaths & 76 & I68 & 136 & 88 \\
Total & &
\end{tabular}

TABLE V

\begin{tabular}{crrr}
\hline \multirow{2}{*}{$\begin{array}{c}\text { Neurological } \\
\text { status before } \\
\text { and after } \\
\text { treatment }\end{array}$} & Conservative & \multicolumn{3}{c}{ Type of treatment } \\
\cline { 2 - 4 } & Early & Late \\
\hline C-3 & I & 5 & - \\
C-2 & 5 & I2 & - \\
C-I & 6 & 9 & I \\
I-n & 2 & 7 & - \\
I-3 & 28 & 30 & 8 \\
I-2 & 26 & 6 & IO \\
C-C & II & 4 I & 27 \\
I-I & 8 & - & 3 \\
Deaths & I00 & I6 & 6 \\
Total & 287 & I26 & 55 \\
\hline
\end{tabular}

of patients with complete spinal cord injury (over 75 per cent). The largest number improving (63 per cent) with simultaneous relatively low mortality (13 per cent) was noted among patients operated on early (up to 3 days from trauma).

\section{Functional status}

Table VI presents the functional status of the group of patients observed, which is expressed by the type of locomotion. Thus, the wheelchair remains the commonest manner of locomotion (over 70 per cent), this is especially so for patients admitted with complete spinal cord injury (93 per cent). On the other hand, from among patients with incomplete injury, the wheelchair is used in only 3I per cent, whereas 35 per cent can walk efficiently and do not require orthopaedic equipment, and 17 per cent walk with the aid of one crutch only or by only using a stick. At the same time it should be emphasised that the mortality in this group is fourfold lower than that observed in those with complete injuries. 


\section{TABLE VI}

\begin{tabular}{lccccc}
\hline $\begin{array}{c}\text { Neurological } \\
\text { status on } \\
\text { admission }\end{array}$ & $\begin{array}{c}\text { Wheel- } \\
\text { chair }\end{array}$ & $\begin{array}{c}\text { Ways of locomotion } \\
\text { crutches }\end{array}$ & $\begin{array}{c}\text { Stick or } \\
\text { a crutch }\end{array}$ & $\begin{array}{c}\text { Without } \\
\text { equipment }\end{array}$ & Deaths \\
\hline Complete & 206 & 8 & 7 & - & I I2 \\
Incomplete & 39 & 20 & 21 & 45 & I0 \\
Total & 245 & 28 & 28 & 45 & I22 \\
\hline
\end{tabular}

\section{Discussion}

The possibility of obtaining neurological and functional improvement in patients with complete or severe symptoms of spinal cord injury is an indisputable matter. This improvement may appear in two forms. Most often it occurs within some I2 hours or so, or after several days from the restoration of normal conditions within the vertebral canal and with spinal stabilisation. The improvement proceeds in various time periods, earlier or later, and in effect it leaves a lesser degree of neurological defect. The mechanism of improvement appears to be clear; early decompression of the spinal cord and its vessels allows resolution of oedema and of ischaemic changes, and also discourages an increase of these changes.

But in cases of incomplete spinal cord injury, with slight preservation of deep sensation in the feet, another phenomenon of neurological improvement may occur, which is difficult to explain. During a period usually of several weeks, symptoms of complete motor paralysis persist; after this period some voluntary movement is possible in the peripheral parts of the lower extremities, which in the following weeks and months gradually regain voluntary motor function. If the increased reflexes and increased muscle tone could be controlled, this improvement could have functional importance. Patients are trained in walking and are discharged from hospital with only minimal orthopaedic appliances, or indeed without any appliance. We wonder what the reason is for the much delayed neurological improvement. Can it be considered to be a sign of regeneration of the damaged segment of the spinal cord? If so, why is this phenomenon not observed in patients with evidence of complete spinal cord injury ? Why do anatomical and pathological investigations not show regeneration features which could have functional importance? Can this phenomenon depend on the survival of hypothetical 'silent pathways' in the spinal cord? Why do they come to light so late, and why are they preceded by clinical signs of spasticity ?

These are the questions which we cannot yet answer, we hope that the clinical experience and studies by neurophysiologists and anatomo-pathologists will provide an explanation for some of these interesting and important clinical problems.

\section{REFERENCES}

Bellamy, R., Pitts, F. W. \& Stauffer, E. S. (1973). Respiratory complications in traumatic quadriplegia. $\mathcal{F}$. Neurosurg., 39, 596.

Bombart, M. \& Senegas, J. (I97I). La phase aigue des tetraplegics traumatiques. Rev. Chir. Orthop., 57, 375. 
BosCh, A., Stauffer, E. S. \& Nickel, V. L. (I97I). Incomplete traumatic quadriplegia. $\mathcal{F} A M A, \mathbf{2 1 6}, 473$.

Bush, G. \& SchürmanN, K. (1971). Anterior fusion in fracture-dislocation and in spontaneous fractures of the cervical spine. Cervical spine operations. Excerpta Medica, Amsterdam, p. 340.

CARTER, R. E. (I977). Traumatic spinal cord injuries due to automobile accidents. South. Med. F., 70, 709 .

ClowaRD, R. B. (I97I). Recent advances in surgery of the cervical spine operations. Excerpta Medica, Amsterdam, p. 285.

Frankel, H. L., HanCock, D. O., Hyslop, G. \& MelzaK, J. (1969). The value of postural reduction in the initial management of closed injuries of the spine. Paraplegia, 7, I79.

HACKLER, R. H. (1977). A 25-year prospective mortality study in the spinal cord injured patient. F. Urol., II7, 486.

HAFTEK, J., RUDNICKI, S. Z. \& Kiwerski, J. (I968). Acute trauma of the cervical segment of the spinal cord. Compensation of the function of the spinal cord. PZWLWarszawa, p. 75.

Heiden, J. S. (I975). Penetrating gunshot wounds of the cervical spine. F. Neurosurg., 42, 575 .

HorlyCK, E. \& RAhbek, M. (1974). Cervical spine injuries. Acta Orthop. Scand., 45, 845.

KIWERSKI, J. (1979). Operative way of reduction of a fracture-dislocation of the cervical spine. Chir. N. Ruchu i Ortop. Pol., 44, 432.

KIWERSKI, J. \& MAKOWSKI, J. (1972). The management in unstable injuries of the cervical spine. Chir. N. Ruchu i Ortop. Pol., 37, 409.

KiwERski, J. \& ChrostowsKa, T. (I977). Mortality rate following cervical spine injuries with spinal cord lesions. Chir. N. Ruchu i Ortop. Pol., 42, 485.

Kiwerski, J., Chrostowska, T. \& MAkowski, J. (I977). Anterior fusion of the injured cervical spine with the use of plate bone graft. Chir. N. Ruchu i Ortop. Pol., 42, I.

MAKOWSKI, J., BIELICKI, B. \& KIWERSKI, J. (I972). The assessment of anterior fusion of the cervical spine. Chir. N. Ruchu $i$ Ortop. Pol., 37, 415.

Mesard, L., Carmody, A. \& MANnarino, E. (I978). Survival after spinal cord trauma. Arch. Neurol., 35, 78.

Meyer, P. R., Rosen, J. S. \& Hamilton, B. B. (1975). Fracture dislocation: cervical spine. East Erie Chicago, 233, I.

MunRo, D. (196I). Cervical spine injuries. New Engl. F. Med., 264, 573.

Selecki, B. R. \& Williams, H. B. L. (1970). Injuries to the cervical spine and cord in man. Australian Med. Publishing Comp., Sydney.

Verbiest, H. (1973). Anterolateral operations for fractures or dislocations of the cervical spine due to injury or previous surgical interventions. Clin. Neurosurg., 20, 334.

Wilcox, N. E., Stauffer, E. S. \& NiCKel, V. L. (I970). A statistical analysis of 423 consecutive patients admitted to the Spinal Cord Injury Center Rancho Los Amigos Hospital. Paraplegia, 8, 27. 